\title{
PEMANFAATAN SAMPAH ORGANIK PASAR SEBAGAI PAKAN IKAN
}

\author{
Fajar Febri Patriatama ${ }^{1)}$
}

\begin{abstract}
Abstrak
Berbagai aktifitas manusia menghasilkan sampah. Semakin banyaknya sampah menimbulkan masalah kesehatan. Sebenarnya, sampah organik masih dapat dapat dimanfaatkan sebagai pakan ternak seperti ikan.

Penelitian eksperimen menguji penambahan dosis sampah organik pada dedak agar dapat menjadi pakan ikan. Variasi perlakuan terdiri dari variasi dosis penambahan hasil fermentasi terhadap bahan pakan. Dengan dosis yang ditambahkan terdiri dari 3 kategori yaitu $25 \%, 45 \%$, dan $65 \%$ untuk setiap $5 \mathrm{Kg}$ bahan baku.

Hasil penelitian mendapatkan bahwa kandungan karbohidrat yang terdapat dalam pakan dengan penambahan dosis sampah organik $25 \%, 45 \%$, dan $65 \%$ memenuhi syarat untuk diberikan kepada ikan herbivora dan omnivora.
\end{abstract}

Kata Kunci: sampah organik, pakan, ikan

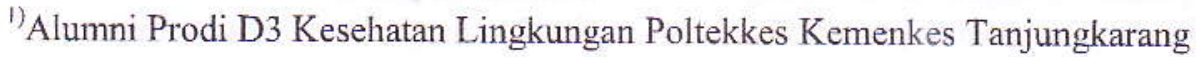

\section{PENDAHULUAN}

Berbagai aktifitas dilakukan oleh manusia untuk memenuhi kesejahteraan hidupnya dengan memproduksi barang dari sumber daya alam. Disamping menghasilkan barang yang akan dikonsumsi manusia, dihasilkan pula bahan buangan yang tidak dibutuhkan lagi oleh manusia. Bahan buangan yang setiap harinya bertambah banyak, berkaitan dengan bertambahnya jumlah penduduk dan di satu pihak ruangan hidup manusia relatif tetap. Jumlah penduduk, tingkat pendapatan, pola konsumsi, pola penyediaan kebutuhan hidup, iklim dan musim merupakan faktor yang dapat mempengaruhi jumlah sampah dari penduduk suatu daerah. Berdasarkan data yang diperoleh jumlah timbunan sampah pada 13 kecamatan di kota Bandar Lampung tahun 2012 terdapat $2258 \mathrm{~m}^{3} /$ hari dengan asumsi gambaran 2,5 liter/orang/hari, sedangkan sampah yang terangkut ke TPA Bakung sebanyak 1176 $\mathrm{m}^{3} /$ hari yang artinya hanya $52 \%$ sampah yang dapat yang dapat dikelola oleh TPA Bakung setiap harinya.

Penanganan sampah yang sering dilakukan hanya mengangkutnya dari tempat sampah di pemukiman kota dan membuangnya ketempat pembuangan sampah akhir atau membakarnya. Cara seperti ini kurang bisa mengatasi masalah sampah karena masih dapat menimbulkan pencemaran lingkungan.Secara sederhana volume sampah dapal dikurangi dengan cara dibakar, namun pembakaran sampah dapat menyebabkan polusi udara. Apalagi jika dilakukan dalam jumlah besar. Hal ini tentu saja kurang baik bagi kesehatan, ratusan jenis senyawa kimia berbahaya yang dapat mengganggu kesehatan manusia, terutama yang bermukim di sekitar tempat pembakaran sampah. Sebaiknya kegiatan penanganan dan pengurangan sampah dilakukan dengan cara pengurangan sampah meliputi kegiatan pembatasan (reduce), penggunaan kembali (reuse) dan pendauran ulang (recycle). Sedangkan kegiatan penanganan sampah meliputi pemilahan, pengumpulan, pengangkutan, pengolahan, dan pemerosesan akhir (Undang- undang RI No. $18 ; 2008$ ).

Selama ini pengolahan limbah maupun sampah organik hanya menitik beratkan pada pengolahan menjadi pupuk kompos, seperti yang diketahui selain menjadi pupuk kompos, sampah organik juga dapat dikelola menjadi bahan bakar (biogas) dan pakan ternak. Bila sampah organik langsung dikomposkan maka prođuk yang di peroleh hanya pupuk organik. Namun bila diolah menjadi pakan, sampah tersebut dapat menghasilkan daging pada ternak dan pupuk organik dari kotoran ternak tersebut. Dengan demikian nilai tambah yang diperoleh akan lebih tinggi sekaligus dapat memecahkan pencemaran lingkungan dan mengatsi 
kekurangan pakan ternak. Membuat pakan dari sampah antara lain dapat dimulai dari pemisahan sampah organik dan anorganik, dilanjutkan dengan pencacahan, fermentasi, pengeringan, penepungan, pencampuran, dan pembuatan pellet (Bestari, dkk, 2011).

\section{METODE}

Penelitian ini merupakan jenis penelitian eksperimen sungguhan (true experiment), peneliti mengontrol semua variabel luar yang mempengaruhi jalannya eksperiment. Adapun rancangan yang digunakan adalah rancangan posttest dengan kelompok kontrol (posttest only kontrol group design), yaitu rancangan yang mengukur perlakuan (intervensi) pada kelompok eksperimen dengan cara membandingkan kelompok tersebut dengan kelompok kontrol. Variasi perlakuan terdiri dari variasi dosis penambahan hasil fermentasi terhadap bahan pakan. Dengan dosis yang ditambahkan terdiri dari 3 kategori yaitu $25 \%$, $45 \%$, dan $65 \%$ untuk setiap $5 \mathrm{Kg}$ bahan baku. Dosis tersebut kemudian disebut dengan dosis 1 untuk $25 \%$, dosis 2 untuk $45 \%$, dan dosis 3 untuk $65 \%$. Setiap variasi dilakukan pengulangan sebanyak dua kali yaitu replikasi 1, dan replikasi 2. Masing masing percobaan menggunakan $5 \mathrm{Kg}$ bahan baku pakan ikan, sehingga bahan baku yang dibutuhkan adalah sebanyak $30 \mathrm{Kg}$.

\section{HASIL}

Dari hasil penelitian yang dilakukan di Workshop Politeknik Kesehatan Tanjung Karang Jurusan Kesehatan Lingkungan dan kemudian dilakukan pemeriksaan di Baristand didapatkan hasil yaitu pengukuran karbohidrat, protein, lemak, pada pakan dengan varian $25 \%$, $45 \%, \quad 65 \%$. Selanjutnya diberikan pada beberapa jenis ikan dengan tingkah laku makan yang berbeda contohnya ikan pemakan tumbuhan (nabati) atau dapat disebut herbivora, contoh ikan herbivora ikan tawes (Puntius javanicus), nilem (Osteochilus haselti), jelawat (Leptobarbus houeveni), sepat siam (Trichogaster pectoralis), bandeng (Chanos chanos), gurami besar (Osphronemus gouramy), dan baronang (Siganus javus), ikan pemakan daging (hewani) atau dapatdisebut karnivora, contoh ikan karnivora gabus (Ophiocephalus striatus), betutu (Oxyeleotris marmorata), sidat (Anguilla sp), oskar (Astronotus ocellatus), belut sawah (Monopterus albus), arwana (Schleropages formosus), kakap putih (Lares calcalifer), kerapu (Ephinephelus sp.), kakap merah (Lutjanus argentimaculatus), dan cucut macan (Galeocerdo rayneri), dan ikan yang dapat memakan segala jenis makanan yang berasal dari hewani dan nabati yang biasa disebut omnivora, salah satu contoh ikan omnivora adalah ikan mas tombro (Cyprinus caprio), mas koki (Carassius auratus), mujair (Tillapia mossambica), dan lele (Clarias batrachus) yang kemudian hasil dari pemeriksaan dan hasil uji coba pemberian pakan tersebut disajikan dalam bentuk tabel dan narasi sebagai berikut :

\section{Nilai Kandungan Pakan Tanpa Pambahan Sampah Organik}

Untuk mengetahui nilai kandungan yang terdapat dalam pakan tanpa penambahan limbah organik memperoleh hasil kandungan protein $11,35 \%$ sedangkan yang dibutuhkan oleh ikan lele, gurami dan patin menurut SNI masingmasing adalah sebesar $30 \%, 32 \%$ dan $25 \%$, maka untuk kandungan protein pada kandungan pakan tanpa penambahan sampah organik dinilai tidak memenuhi syarat sebagai pakan ikan tersebut. Kandungan karbohidrat sebesar $28,62 \%$ memenuhi syarat untuk jenis ikan herbivora dan omnivora tetapi tidak cocok untuk karnivora. Hasil perhitungan kandungan lemak sebesae $12,15 \%$ juga tidak memenuhi syarat sebagai pakan ikan.

\section{Nilai Kandungan Pakan Dengan Varian $25 \%$ dan $45 \%$}

Untuk mengetahui nilai kandungan yang terdapat dalam pakan dengan varian $25 \%$ dapat dilihat pada Tabel 1. Dari tabel diketahui bahwa untuk parameter karbohidrat telah memenuhi standar untuk digunakan pada jenis ikan herbivora dan omnivora namun untuk parameter protein dan lemak masih belum memenuhi standar pakan ikan menurut SNI.

Untuk mengetahui nilai kandungan yang terdapat dalam pakan dengan varian $45 \%$ dapat dilihat pada Tabel 2. 
Tabel 1. Nilai Kandungan Yang Terdapat Dalam Pakan Dengan Varian 25\% Yang Dibandingkan Dengan SNI 01-408-2006, SNI 7548-2009, SNI 7473-2009

\begin{tabular}{|c|c|c|c|c|c|c|c|}
\hline \multirow[b]{2}{*}{ NO } & \multirow[b]{2}{*}{ PARAMETER } & \multirow[b]{2}{*}{ HASIL } & \multicolumn{4}{|c|}{ STANDAR IKAN } & \multirow[b]{2}{*}{ KET } \\
\hline & & & $\begin{array}{l}\text { JENIS } \\
\text { IKAN }\end{array}$ & LELE & GURAMI & PATIN & \\
\hline 1 & Protein & $13,8 \%$ & & $30 \%$ & $32 \%$ & $25 \%$ & TMS \\
\hline \multirow{3}{*}{2} & \multirow{3}{*}{ Karbohidrat } & \multirow{3}{*}{$31,65 \%$} & Herbivora & & $30 \mathrm{~s} / \mathrm{d} 40 \%$ & & MS \\
\hline & & & Omnivora & & $25 \mathrm{~s} / \mathrm{d} 35 \%$ & & MS \\
\hline & & & Karnivora & & $15 \mathrm{~s} / \mathrm{d} 20 \%$ & & TMS \\
\hline 3 & Lemak & $12,26 \%$ & & $5 \%$ & $6 \%$ & $5 \%$ & TMS \\
\hline
\end{tabular}

Tabel 2. Nilai Kandungan Yang Terdapat Dalam Pakan Dengan Varian 45\% Yang Dibandingkan Dengan SNI 01-408-2006, SNI 7548-2009, SNI 7473-2009

\begin{tabular}{|c|c|c|c|c|c|c|c|}
\hline \multirow[b]{2}{*}{ NO } & \multirow[b]{2}{*}{ PARAMETER } & \multirow[b]{2}{*}{ HASIL } & \multicolumn{4}{|c|}{ STANDAR IKAN } & \multirow[b]{2}{*}{ KET } \\
\hline & & & $\begin{array}{l}\text { JENIS } \\
\text { IKAN }\end{array}$ & LELE & GURAMI & PATIN & \\
\hline 1 & Protein & $11,8 \%$ & & $30 \%$ & $32 \%$ & $25 \%$ & TMS \\
\hline 2 & Karbohidrat & $32,07 \%$ & $\begin{array}{l}\text { Herbivora } \\
\text { Omnivora } \\
\text { Karnivora }\end{array}$ & & $\begin{array}{l}30 \mathrm{~s} / \mathrm{d} 40 \% \\
25 \mathrm{~s} / \mathrm{d} 35 \% \\
15 \mathrm{~s} / \mathrm{d} 20 \%\end{array}$ & & $\begin{array}{c}\text { MS } \\
\text { MS } \\
\text { TMS }\end{array}$ \\
\hline 3 & Lemak & $12,76 \%$ & & $5 \%$ & $6 \%$ & $5 \%$ & TMS \\
\hline
\end{tabular}

Dari tabel 2 diketahui bahwa untuk parameter karbohidrat telah memenuhi standar untuk digunakan pada jenis ikan herbivora dan omnivora, sedangkan terjadi penurunan pada kadar protein sehingga untuk parameter protein dan lemak masih belum memenuhi standar pakan ikan menurut SNI.

\section{Nilai Kandungan Pakan Dengan Varian $65 \%$}

Untuk mengetahui nilai kandungan yang terdapat dalam pakan dengan varian $65 \%$ dapat dilihat pada tabel 3. Disimpulkan bahwa untuk parameter karbohidrat telah memenuhi standar untuk digunakan pada jenis ikan herbivora dan omnivora, sedangkan terjadi penurunan pada kadar protein sehingga untuk parametrer protein dan lemak masih belum memenuhi standar pakan ikan menurut SNI.

Tabel 3. Nilai Kandungan Yang Terdapat Dalam Pakan Dengan Varian $65 \%$ Yang Dibandingkan Dengan SNI 01-408-2006, SNI 7548-2009, SNI 7473-2009

\begin{tabular}{llcccccc}
\hline \multirow{2}{*}{ NO } & \multirow{2}{*}{ PARAMETER } & \multirow{2}{*}{ HASIL } & $\begin{array}{c}\text { JENIS } \\
\text { IKAN }\end{array}$ & LELE & GURAMI & PATIN & \multirow{2}{*}{ KET } \\
\hline 1 & Protein & 12,57 & & $30 \%$ & $32 \%$ & $25 \%$ & TMS \\
& & & Herbivora & & $30 \mathrm{~s} / \mathrm{d} 40 \%$ & & MS \\
2 & Karbohidrat & 32,18 & $\begin{array}{c}\text { Omnivora } \\
\text { Karnivora }\end{array}$ & & $25 \mathrm{~s} / \mathrm{d} 35 \%$ & & MS \\
3 & Lemak & 12,62 & & $5 \%$ & $6 \%$ & $5 \%$ & TMS \\
\hline
\end{tabular}

\section{Uji Pakan}

Uji coba daya daya apung dilakukan untuk mengetahui jenis apakah pakan tersebut jenis pakan apung, pakan tenggelam perlahan, pakan tenggelam, atau remah. Pada uji coba terlihat pakan tenggelam. 


\section{PEMBAHASAN}

Sampah organik yang dikumpulkan untuk penelitian ini di dapat dari pasar Natar, yang kemudian dilakukan pemilahan lagi, dikarnakan masih banyak sampah organik dan anorganik yang tercampur. Kemudian sampah organik tersebut di cacah hingga berukuran $\pm 2 \mathrm{~s} / \mathrm{d} 3,5$ $\mathrm{cm}$, hasil cacahan tersebut kemudian dimasukan kedalam drum $200 \mathrm{~L}$ dan ditambahkan \pm 54 liter air dan $110 \mathrm{ml}$ EM4. Drum tersebut ditutp rapat dengan menggunakan tutup yang diberi tambahan ring sehingga tidak terdapat udara yang dapat keluar maupun masuk. Perubahan warna pada air di dalam botol menjadi sedikit berwarna kekuningan menandakan bahwa fermentasi telah berlangsung.

Waktu pematangan fermentasi berlangsung selama 5 hari, kemudian dilakukan pengecekan untu memastikan apakah fermentasi telah matang, dengan melakukan pengamatan tersebut didapat bahwa aroma dan tekstur pada sampah mulai berubah. Pembuatan pakan ikan dengan cara mencampur dedak dan sampah dengan mengunakan beberapa varian yaitu $25 \%$ sampah fermentasi ditambah $75 \%$ dedak, $45 \%$ sampah fermentasi ditambah $55 \%$ dedak, $65 \%$ sampah fermentasi ditambah $35 \%$ dedak, dan untuk kontrol $100 \%$ dedak yang ditambah $100 \mathrm{ml}$ air, yang kemudian bahan-bahan tersebut dicampur dengan menggunakan gilingan daging. Pakan tersebut kemudian dijemur selama 3 hari dengan menggunakan tenaga matahari agar kadar airnya berkurang. Pakan tersebut kemudian diperiksa kandungan protein, lemak, dan karbohidratnya, dengan hasil sebagai berikut :

\section{Protein}

Protein merupakan enzim yang sangat berperan dalam pencernaan (pencarnaan protein juga disebut proteinase) baik yang terdapat di lambung, pankreas, maupun dinding usus. Di lambung protein dalam pakan akan mengalami denaturalisator oleh $\mathrm{HCL}$ dan dihidrolis dengan katalisator enzim pepsin, protein yang dicerna tersebut akan berubah menjadi peptid. Pencernaan di lambung merupakan persiapan untuk pencernaan di usus.

Di usus, peptid akan mengalami hidrolisa dengan enzim karboksipeptidase, tripsin, khimotripsin, dan elastase sebagai katalisatornya, menjadi polipeptid, tripeptid, dan dipeptid. Enzim tersebuut di sekersikan oleh pankreas eksorsin. Selanjutnya oligopeptid ini akan di hidrolisis dengan enzim peptidase yang disekersikan oleh dinding usus sebagai katalisatornya, sehingga menjadi tripeptid, dipeptid, dan asam amino. Hidrolisis berikutnya untuk senyawa berikutnya untuk senyawa tripeptid dan dipeptid dilakukan enzim tripeptidase dan dipeptidase hingga akhirnya menjadi asam amino. Pada ikan yang memiliki pilorik, kaeka, hidrolisis protein, dikalisasi oleh enzim yang berasal dari pankreas. Pada ikan yang tidak memiliki lambung pencernaan protein terjadi di usus depan dengan demikian enzim protozease yang bekerja dalam hidrolisis protein tersebut terutama berasal dari pankreas. Untuk mencapai hasil hidrolisis yang maksimal dan untuk memaksimalkan kemampuan pengasimilasi nutrien, ikan-ikan tersebut yang tidak berlambung biasanya memiliki usus yanng panjang. Demikian pula halnya dengan ikan yang baru menetas, pada stadia larva, lambung belum terbentuk sehingga fungsi lambung digantikan oleh usus depan. Dalam hal ini makanan yang dimakan ditampung di usus depan, di tempat itu pula pencernaan protein, lemak dan karbohidrat dimulai. Larva ikan baik yang nantinya akan menjadi ikan karnivora, herbivora, maupun omnivora memiliki usus yang pendek. Dengan demikian kompensasi larva ikan untuk melakukan proses pencernaan dan penyerapan nutrien ialah dengan cara memakan hewan renik Zooplankton ini selain mengandung nilai gizi yang tinggi juga mudah dicerna karena mengandung enzim yang dapat berperan dalam autolisis.

Sebagai akibat adanya HCL pada lambung, makanan yang dimakan mengalami pengasaman sehiungga ketika makanan yang sudah berbentuk bubur, $\mathrm{pH}$ nya rendah makan. Ketika chyme masuk ke usus depan, chyme akan bercampur dengan empedu dan cairan pankreas yang selain mengandung enzim juga banyak mengandung bikarbonat. Carian empedu dan cairan pankreas yang selain mengandung enzim juga mengandung biokarbonat. Cairan empedu yang sifatnya basa dan adanya ion bikarbonat dari pankreas menyebabkan naiknya $\mathrm{Ph}$ chyme pada usus. Dengan kondisi $\mathrm{Ph}$ chyme yang basa, maka enzim pankreatik dan enzim dari mukosa usus dapat bekerja secara optimal.

Protein adalah senyawa organik kompleks yang tersusun atas banyak asam amino. Protein dapat berasal dari tumbuhan maupun hewan. Protein dari tumbuhan / nabati biasanya lebih sulit dicerna ikan karena terbungkus selulosa. 
Kandungan asam amino pada protein nabati kurang lengkap sehingga perlu ditambah dengan protein hewani. Protein merupakan unsur yang paling penting dalam pakan. Fungsi utama protein dalam metabolisme ikan adalah berperan sebagai pembangun jaringan tubuh, mengganti jaringan tubuh yang rusak, berperan dalam reproduksi, komponen utama penyusun enzim dan hormon, dan berperan dalam proses metabolisme dalam tubuh ikan. Ikan golongan karnivora membutuhkan protein lebih besar dibanding ikan herbivora dan omnivora.

Kandungan protein optimum pakan ikan adalah $25-35 \%$. Hasil penelitian kadar protein pada varian $25 \%$ adalah $14,38 \%$, varian $45 \%$ adalah $12,03 \%$, dan pada varian $65 \%$ adalah $12,48 \%$. Terjadi penurunan kandungan protein pada varian $45 \%$ yang kemungkinan disebabkan oleh pencampuran yang kurang merata. Sehingga dapat disimpulkan bahwa kadar protein yang terdapat pada pakan dengan varian $25 \%, 45 \%, 65 \%$, dan tanpa penambahan hasil fermentasi dapat dikatakan belum memenuhi standar yang dibutukan ikan untuk perkembangannya. Sebaiknya untuk meningkatkan kandungan protein pada pakan perlu ditambahkan beberapa bahan bahan lain seperti keong sawah, tepung darah, dan sebagainya agar proteinnya meningkat.

\section{Karbohidrat}

Karbohidrat dalam pakan ikan umumnya berbentuk senyawa polisakarida, disakarida, dan monosakarida. Karbohidrat tersebut dapat berasal dari tumbuhan (zat tepung, serat, selulosa, dan fruktosa) dan dari tubuh hewan yaitu berbentuk glicogcen. Karna ikan tidak memiliki air liur, maka pencernaan karbohidrat dimulai di lambung. Walaupun tidak banyak pustaka yang menjelaskan tentang pencernaan karbohidrat di segmen lambung namun pada ikan gabus dan ikan belanak aktivitas amilase pada lambung. Seshadri (1967) dalam Kapoor et. al (1975). Pencernaan karbohidrat secara intensif terjadi di segmen usus yaitu dengan adanya enzim amlase pankreatik. Pada usus, amilum (zat tepung) dan glikogen dihidrolisis oleh enzim amilase menjadi maitose dan dekstrin. Kemudian maltose dan dekstrin ini akan dihirolis oleh enzim laktase yang yang kemudian menjadi glukosa. Disakarida dihidrolisis oleh enzim laktase atau surkase menghasilkan galaktosa, glukosa, dan fruktosa. Pada dinding usus galaktosa dan fruktosa akan diubah menjadi glukosa. Selulosa akan dihidrolisis dengan enzim selulase sebagai katalisatornya menjadi selobiose, yang kemudian akan di hidrolisis dengan enzim selobiase sebagai katalisatornya menjadi glukosa. Dengan bentuk glukosa ini karbohidrat dapat diserap oleh dinding sel (enterosit).

Beberapa contoh bahan yang mengadung karbohidrat antara lain jagung, dedak, tapioka, dan sagu. Seperti yang diketahui karbohidrat menjadi sumber energi bagi ikan, bisa dimanfaatkan secara langsung menjadi energi Kebutuhan ikan akan karbohidrat dipengaruhi oleh jenis ikan. Ikan herbivora seperti Gurami, Tawes, Nilem membutuhkan karbohidrat lebih besar dibanding jenis omnivora dan karnivora. Ikan jenis herbivora mempunyai daya cerna karbohidrat yang lebih tinggi.

Kebutuhan karbohidrat pada ikan herbivora adalah antara 30-40 \%, Omnivora $25-35 \%$, dan karnivora 15-20 \%. Hasil penelitian memperoleh kadar karbohidrat pada varian 25 $\%$ adalah $31,41 \%$, varian $45 \%$ adalah 33,24 $\%$, dan pada varian $65 \%$ adalah $32,49 \%$. Yang dapat disimpulkan bahwa kadar karbohidrat yang terdapat pada pakan dengan varian $25 \%$, $45 \%$, dan $65 \%$ dapat dikatakan telah memenuhi standar untuk diberikan pada ikan herbivora dan omnivora, tetapi untuk diberikan pada jenis ikan karnivora tidak dianjurkan dikarnakan kebutuhan karbohidrat untuk ikan jenis tersebut hanya $15-20 \%$

\section{Lemak}

Pencernaan lemak pada ikan dimulai di bagian lambung, akan tetapi pencernaan di sini tidak begitu efektif. Pencernaan lemak secara intensif terjadi dibagian usus, dalam hal ini lemak di hidrolisis dengan katalisator enzim lipase pankreatik. Enzim lipase pankreatik meng hidrolisis trigiselid menjadi monoglisetid dan asam lemak. Hampir $80 \%$ lemak yang dikonsumsi, hidrolisis nya dikatalisis oleh enzim pankreatik. Dehidrolisa dengan adanya garam empedu yang berfungsi sebagai pengemulsi lemak berukuran kecil yang discbut "micelles". Micelles ini umumnya mengandung asam lemak, monogliserid dan kolestrol. Partikel lemak dalam bentuk micelles ini siap untuk diserap oleh dinding usus (enterosit). Didapatkan hasil penelitian kadar lemak pada varian $25 \%$ adalah $12,17 \%$, varian $45 \%$ adalah $12,63 \%$, dan pada varian $65 \%$ adalah $12,53 \%$. Lemak berfungsi sebagai sumber energi. Dalam formulasi pakan, lemak juga berpengauh pada daya apung ikan di 
permukaan air. kandungan lemak pada pakan yang baik adalah $5 \%$.

Lemak yang berlebih pada pakan tidak baik bagi kesehatan ikan karena pakan menjadi mudah teroksidasi sehingga baunya menjadi tidak enak. Sehingga dapat disimpulkan bahwa kadar lemak yang terdapat pada pakan dengan varian $25 \%, 45 \%, 65 \%$, dan tanpa penambahan hasil fermentasi dapat diketahui belum memenuhi standar untuk diberikan pada semua jenis ikan.

\section{Tahap Uji Coba}

\section{a. Uji Coba Daya Apung}

Uji coba daya daya apung dilakukan untuk mengetahui jenis apakah pakan tersebut jenis pakan apung, pakan tenggelam perlahan, pakan tenggelam. Pada uji coba terlihat pakan mengapung sesaat sebelum tenggelam sehingga dapat disimpulakan bahawa jenis pakan yang dihasilkan adalah pakan tenggelam. Sebaiknya agar pakan dapat mengapung semua bahanbahan yang akan digunakan dalam pembuatan pakan ikan diubah menjadi tepung terlebih dahulu agar tekstur pakan menjadi lebih halus dan pakan menjadi lebih ringan.

\section{b. Uji Coba Pakan}

Telah dilakukan uji coba pemberian pakan terhadap ikan, untuk uji coba pertama dilakukan di rumah dengan jenis ikan patin, namun dikarnakan ukuran ikan yang kecil, pakan tersebut masih sulit untuk dimakan. Untuk uji coba kedua dilakukan di kampus jurusan kesehatan lingkungan dengan jenis ikan koi, hanya ikan ikan mas koi yang berukuran besar saja yang dapat memakan pakan dan masih terlihat kesulitan memakan pakan tersebut. Pakan yang dimakan adalah pakan dengan varian $25 \%$ dan $45 \%$. Untuk uji coba ketiga dilakukan di waylayap dengan jenis ikan mas dan lele, setelah diuji cobakan pada ikan hanya pkan dengan varian $25 \%$ dan $45 \%$ saja yang dimakan. Agar pakan disukai ikan sebaiknya perlu adanya pemilihan bahan baku dalam pembuatan pakan yang disukai ikan, perlu adanya penyesuaian ukuran pakan sesuai dengan usia ikan, dan nutrisi pada pakan perlu ditingkatkan.

\section{KESIMPULAN}

Dari uji pemanfaatan sampah organik pasar menjadi pakan ikan, jenis pakan ikan yang dihasilkan pada penelitian ini adalah pakan ikan tenggelam yang dapat dimanfaatkan sebabagi pakan ikan herbivora dan omnivora..

\section{DAFTAR PUSTAKA}

Depertemen Kesehatan RI, 2002. Keputusan Mentri Kelautan Dan Perikanan RI. No.45/Men/2004 tentang Pengadaan Dan Peredaran Pakan Ikan, 27 halaman.

Undang - Undang RI, 2008. Undang - undang Nomor 18/2008 Tentang Pengelolaan Sampah. Jakarta: RI.

Notoadmodjo, ${ }^{2}$ 2010. Metodologi Penelitian Kesehatan. Jakarta: Rincka Cipta. 243 halaman.

RGB, Gunawan, 2015. Membuat Sendiri Pakan Ikan Murah \& Praktis. Jakarta: AgroMedia Pustaka. 94 halaman.

Dharmawan, 2015. Usaha Pembuatan Pakan Ikan Konsumsi. Yogyakarta: Pustaka Baru Press 176 halaman.

Utama, CS., Mulyanto, A., 2009. Potensi Limbah Pasar Menjadi Starter Fermentasi, Jurnal kesehatan. Jurusan Nutisi Dan Makanan Ternak Fakultas Peternakan Universitas Diponegoro Semarang

Wikanastri., Utama, Cahya S., Suyanto, Agus., 2012. Aplikasi Proses Fermentasi Kulit Singkong Menggunakan Starter Asal Limbah Kubis Dan Sawi Pada Pembuatan Pakan Temak Berpotensi Probiotik, Program Studi Teknologi Pangan Universitas Muhammadiyah Semarang

Haryanto, Budi., Supriyati, A Thalib., Jarmani SN, 2005. Peningkatan Nilai Hayati Jerami Padi Melalui Bio-Proses Fermentatif Dan Penambahan Zinc Organik, jumal Balai Penelitian Ternak.

Pardaes, Panji Bernade, 2015. Pemanfaatan Limbah Darah Sapi Rumah Potong Hewan CV. Zaky Putra Pratama Sebagai Tambahan Dalam Pembuatan Kompos Tahun 2015, Karya Tulis Ilmiah Poltekkes Tanjungkarang. 